\title{
Association between invasiveness, inflammatory reaction, desmoplasia and survival in colorectal cancer
}

\author{
T B HALVORSEN, ${ }^{*}$ EVA SEIM $\dagger$ \\ From the *Department of Pathology, Trondheim Regional and University Hospital, and the $†$ Department of \\ Mathematics and Statistics, University of Trondheim, Norway
}

SUMMARY Five hundred and twenty seven colorectal carcinomas were reviewed histologically. A multivariate analysis (Cox) was used to test the prognostic importance of certain histological features (invasiveness, inflammatory reaction, and amount of fibrous tissue) at the tumour edge after allowance had been made for clinicopathological stage, tumour site, and histological type and grade. A poorly defined tumour border, lack of inflammatory reaction, and a pronounced fibrosis (desmoplasia) at the tumour edge were associated with unfavourable stage distributions, but each of these features also had an independent effect on prognosis.

Highly invasive or expanding growth have repeatedly been shown to worsen the prognosis in colorectal cancer. ${ }^{1-4}$ A pronounced inflammatory reaction in the stroma at the tumour edge, on the other hand, has often been associated with an improved prognosis. ${ }^{25-11}$ Sometimes a pronounced peritumoural fibrosis (desmoplasia) is observed. The biological role of this feature has been debated..$^{12-14}$

This study was undertaken to evaluate the prognostic importance of invasiveness, inflammatory reaction, and desmoplasia in colorectal cancer, and the association between these morphological features and other prognostic factors such as tumour stage, grade, and site.

\section{Material and methods}

The histological material from 534 surgically removed colorectal adenocarcinomas were re-examined blind by one observer. The grading of these tumours according to the predominant degree of differentiation and their classification with regard to mucin content has previously been reported ${ }^{1516}$ Signet ring-cell carcinomas were not graded. The tumours were categorised by site-right colon, left colon, and rectum. ${ }^{17}$ Staging was performed according to Dukes' classification. ${ }^{18}$ Tumours with distant spread or growth beyond the surgical margins formed a separate stage designated "advanced disease", also known as "Dukes D". The invasiveness of the tumour was scored as follows: score $0=$ well defined border with expanding growth; and score $1=$ poorly defined

Accepted for publication 29 September 1988 border with pronounced invasive growth (fig 1).

The inflammatory reaction was assessed on the basis of the general impression of the amount of inflammatory cells along the entire tumour edge away from areas of frank abscess formation, and scored as follows: score $0=$ prominent inflammatory infiltrate (fig 2); and score $1=$ inconspicuous inflammatory infiltrate. No attempt was made to evaluate the proportions of the various inflammatory cells unless many eosinophils were observed, in which case the infiltrates were classified as "eosinophilic". The presence of abscesses was also noted separately. Finally, the presence of perivascular collections ("cuffs") of lymphocytes ${ }^{7}$ was noted, even if they were

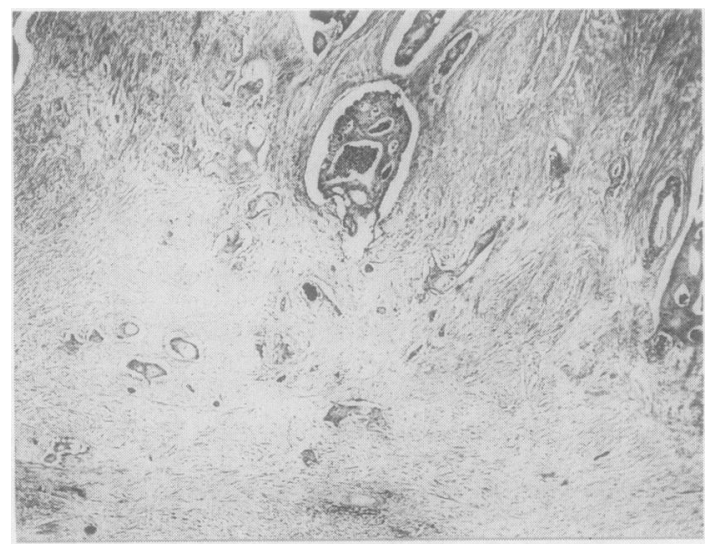

Fig 1 Colonic adenocarcinoma with pronounced invasive growth and extensive fibrosis at the tumour edge.

(Haematoxylin-eosin-saffron.) 


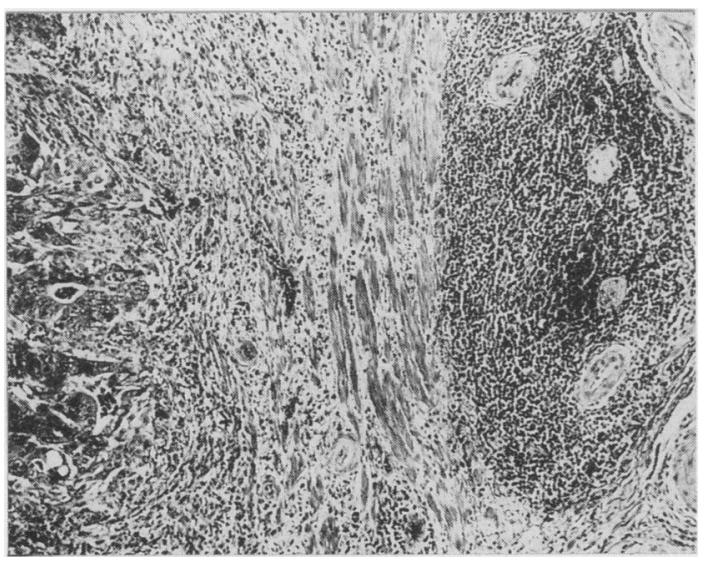

Fig 2 Colonic adenocarcinoma with pronounced inflammatory reaction including perivascular lymphocytic cuffs at tumour edge. (Haematoxylin-eosin-saffron.)

located at some distance from the tumour margin itself (fig 2).

The amount of fibrous tissue was assessed at the advancing tumour edge and was scored as follows: score $\mathbf{0}=$ little or moderate amount of fibrosis; and score 1 = desmoplasia, with extensive fibrosis accounting for at least an equal amount of tissue as the carcinoma itself (fig 1).

Seven cases in which histological assessment could not be performed were excluded. Five hundred and twenty seven tumours from 271 men and 256 women remained. The mean ages were 66.0 (SEM 0.6) and $64.7(0.7)$ years for men and women, respectively.

Survival data for the patients in this series were obtained from the files of the Cancer Registry of Norway up to the end of September 1985. Death due to colorectal cancer was used as the clinical end point. Cut off was 85 years of age. The survival function was estimated by Cox's proportional hazards regression analysis ${ }^{19}$ using the computer program BMDP $2 \mathrm{~L},{ }^{20}$ as explained in detail in a previous report. ${ }^{15}$

Cohen's $\kappa$ statistic $^{21}$ was used to estimate the reproducibility of the histological evaluations in 212 randomly selected cases.

\section{Results}

The stage distributions were more favourable in tumours with a well defined border, prominent inflammatory reaction, eosinophilia and lack of definite

Table 1 Stage distribution by tumour border characteristics in 527 colorectal carcinomas

\begin{tabular}{|c|c|c|c|c|c|}
\hline \multirow[b]{2}{*}{$\begin{array}{l}\text { Tumour border } \\
\text { characteristics }\end{array}$} & \multirow[b]{2}{*}{$\begin{array}{l}\text { No of } \\
\text { cases }\end{array}$} & \multicolumn{4}{|c|}{ Clinicopathological stage (\%) } \\
\hline & & $\begin{array}{l}\text { Dukes' } \\
\text { A }\end{array}$ & $\begin{array}{l}\text { Dukes' } \\
B\end{array}$ & $\begin{array}{l}\text { Dukes' } \\
\text { C }\end{array}$ & $\begin{array}{l}\text { Advanced } \\
\text { disease }\end{array}$ \\
\hline $\begin{array}{l}\text { Well defined border } \\
\text { Poorly defined border }\end{array}$ & $\begin{array}{l}393 \\
134\end{array}$ & $\begin{array}{r}18 \\
1\end{array}$ & $\begin{array}{l}50 \\
34\end{array}$ & $\begin{array}{l}19 \\
45\end{array}$ & $\begin{array}{l}13 \\
20\end{array}$ \\
\hline $\begin{array}{l}\text { Inflammation + * } \\
\text { Inflammation - }\end{array}$ & $\begin{array}{l}181 \\
346\end{array}$ & $\begin{array}{l}20 \\
10\end{array}$ & $\begin{array}{l}48 \\
44\end{array}$ & $\begin{array}{l}19 \\
30\end{array}$ & $\begin{array}{l}13 \\
16\end{array}$ \\
\hline $\begin{array}{l}\text { Lymphocytic cuffs + } \\
\text { Lymphocytic cuffs - }\end{array}$ & $\begin{array}{l}345 \\
182\end{array}$ & $\begin{array}{l}13 \\
15\end{array}$ & $\begin{array}{l}48 \\
42\end{array}$ & $\begin{array}{l}26 \\
26\end{array}$ & $\begin{array}{l}13 \\
17\end{array}$ \\
\hline $\begin{array}{l}\text { Eosinophilia + } \\
\text { Eosinophilia - }\end{array}$ & $\begin{array}{r}26 \\
501\end{array}$ & $\begin{array}{l}35 \\
12\end{array}$ & $\begin{array}{l}35 \\
47\end{array}$ & $\begin{array}{l}27 \\
26\end{array}$ & $\begin{array}{r}3 \\
15\end{array}$ \\
\hline $\begin{array}{l}\text { Abscesses + } \\
\text { Abscesses - }\end{array}$ & $\begin{array}{r}97 \\
430\end{array}$ & $\begin{array}{l}12 \\
13\end{array}$ & $\begin{array}{l}56 \\
44\end{array}$ & $\begin{array}{l}13 \\
29\end{array}$ & $\begin{array}{l}19 \\
14\end{array}$ \\
\hline $\begin{array}{l}\text { Desmoplasia + } \\
\text { Desmoplasia - }\end{array}$ & $\begin{array}{l}353 \\
174\end{array}$ & $\begin{array}{r}7 \\
26\end{array}$ & $\begin{array}{l}46 \\
46\end{array}$ & $\begin{array}{l}31 \\
17\end{array}$ & $\begin{array}{l}16 \\
11\end{array}$ \\
\hline All & 527 & 13 & 46 & 26 & 15 \\
\hline
\end{tabular}

"+ signifies "prominent" or "conspicuous" - signifies absence. †Denotes distant spread or tumour growth beyond surgical margins.

Table 2 Growth pattern at tumour edge according to overall histological grade (percentages in parentheses)

\begin{tabular}{|c|c|c|c|c|}
\hline \multirow[b]{2}{*}{ Growth } & \multicolumn{4}{|c|}{ Histological grade } \\
\hline & $\begin{array}{l}\text { Well } \\
\text { differentiated }\end{array}$ & $\begin{array}{l}\text { Moderately } \\
\text { differentiated }\end{array}$ & $\begin{array}{l}\text { Poorly } \\
\text { differentiated }\end{array}$ & All grades \\
\hline $\begin{array}{l}\text { Well defined border } \\
\text { Poorly defined border }\end{array}$ & $\begin{array}{r}155(89) \\
19(11)\end{array}$ & $\begin{array}{r}209(75) \\
68(25)\end{array}$ & $\begin{array}{l}21(32) \\
44(68)\end{array}$ & $\begin{array}{l}385(75) \\
131(25)\end{array}$ \\
\hline All & 174 & 277 & 65 & $516^{*}$ \\
\hline
\end{tabular}

*Eleven signet ring-cell carcinomas were excluded from this table. 
Table 3 Inflammatory reaction and desmoplasia according to growth pattern at the tumour border in 527 colorectal carcinomas

\begin{tabular}{|c|c|c|c|}
\hline \multirow[b]{2}{*}{$\begin{array}{l}\text { Inflammatory reaction } \\
\text { and desmoplasia }\end{array}$} & \multicolumn{3}{|c|}{ Growth pattern at the tumour border: } \\
\hline & $\begin{array}{l}\text { Well } \\
\text { defined } \\
\text { border }\end{array}$ & $\begin{array}{l}\text { Poorly } \\
\text { defined } \\
\text { border }\end{array}$ & p-Value $\ddagger$ \\
\hline $\begin{array}{l}\text { Inflammation +* } \\
\text { Inflammation- }\end{array}$ & $\begin{array}{l}162 \\
231\end{array}$ & $\begin{array}{r}19 \\
115\end{array}$ & $<0.0001$ \\
\hline $\begin{array}{l}\text { Lymphocytic cuffs + } \\
\text { Lymphocytic cuffs - }\end{array}$ & $\begin{array}{l}266 \\
127\end{array}$ & $\begin{array}{l}79 \\
55\end{array}$ & $>0.05$ \\
\hline $\begin{array}{l}\text { Eosinophilia + } \\
\text { Eosinophilia - }\end{array}$ & $\begin{array}{r}26 \\
367\end{array}$ & $\begin{array}{r}0 \\
134\end{array}$ & $<0.005$ \\
\hline $\begin{array}{l}\text { Abscesses + } \\
\text { Abscesses - }\end{array}$ & $\begin{array}{r}83 \\
310\end{array}$ & $\begin{array}{r}14 \\
120\end{array}$ & $<0.01$ \\
\hline $\begin{array}{l}\text { Desmoplasia + } \\
\text { Desmoplasia - }\end{array}$ & $\begin{array}{l}240 \\
153\end{array}$ & $\begin{array}{r}113 \\
21\end{array}$ & $<0.0001$ \\
\hline
\end{tabular}

"+ signifies "prominent" or "conspicuous". - signifies absence.

$\ddagger$ Based on $\chi^{2}$ test with one degree of freedom.

desmoplastic reaction than in tumours with "opposite" characteristics (table 1).

Tumours with poorly defined border were less differentiated than their well defined counterparts $\left(\chi^{2}=80.74 ; \mathrm{df}=2 ; \mathrm{p}<0.0001\right)$ (table 2). None of the other tumour border characteristics were significantly correlated with histological grade (data not shown).

Only one of $11(9 \%)$ signet ring-cell carcinomas exhibited a pronounced inflammatory reaction compared with 180 of $516(35 \%)$ of the others $(p<0.01)$. Desmoplastic reaction was found in only two $(18 \%)$ of the signet ring-cell carcinomas compared with 351 of

Table 4 Final model in proportional hazards regression analysis

\begin{tabular}{|c|c|c|}
\hline Explanatory variable & $\begin{array}{l}\text { Regression } \\
\text { coefficient } \\
(S E)\end{array}$ & $\begin{array}{l}\text { Relative } \\
\text { risk ( } 95 \% \\
\text { confidence } \\
\text { limits) }\end{array}$ \\
\hline $\begin{array}{l}\text { Tumour site: } \\
\text { Left colon } v \text { right colon } \\
\text { Rectum } v \text { right colon }\end{array}$ & $\begin{array}{l}0.678(0.219) \\
1 \cdot 289(0.222)\end{array}$ & $\begin{array}{l}1.97(1.27 ; 3.05) \\
3.63(2.33 ; 5.65)\end{array}$ \\
\hline $\begin{array}{l}\text { Clinicopathological stage: } \\
\text { Dukes' B v Dukes' A } \\
\text { Dukes' C v Dukes' A } \\
\text { Advanced disease } v \text { Dukes' A }\end{array}$ & $\begin{array}{l}0.662(0.282) \\
1 \cdot 118(0.294) \\
1.782(0.306)\end{array}$ & $\begin{array}{l}1.94(1 \cdot 10 ; 3.41) \\
3.06(1 \cdot 70 ; 5 \cdot 51) \\
5.94(3 \cdot 22 ; 10 \cdot 96)\end{array}$ \\
\hline $\begin{array}{l}\text { Histological grade: } \\
\text { Moderate } v \text { well differentiation } \\
\text { Poor } v \text { well differentiation }\end{array}$ & $\begin{array}{l}0.406(0.165) \\
1.135(0.226)\end{array}$ & $\begin{array}{l}1 \cdot 50(1.08 ; 2.09) \\
3.11(1.98 ; 4.89)\end{array}$ \\
\hline $\begin{array}{l}\text { Histological type: } \\
\text { Signet ring-cell carcinoma } v \\
\text { adenocarcinoma }\end{array}$ & $1.735(0.475)$ & $5.67(2 \cdot 19 ; 14 \cdot 66)$ \\
\hline $\begin{array}{l}\text { Tumour border characteristics: } \\
\text { Poorly defined border } \\
\text { Lack of prominent inflammatory } \\
\text { reaction } \\
\text { Lack of perivascular } \\
\text { lymphocytic cuffs } \\
\text { Desmoplastic reaction }\end{array}$ & $\begin{array}{l}0.495(0 \cdot 152) \\
0.363(0 \cdot 160) \\
0.381(0.137) \\
0.450(0.166)\end{array}$ & $\begin{array}{l}1.64(1.21 ; 2.23) \\
1.44(1.05 ; 1.98) \\
1.46(1.11 ; 1.92) \\
1.57(1.13 ; 2.19)\end{array}$ \\
\hline
\end{tabular}

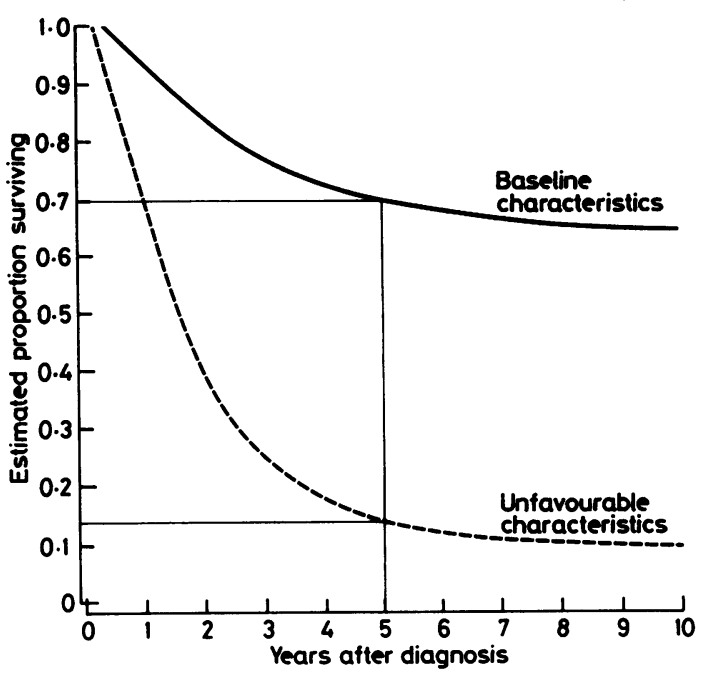

Fig 3 Estimated survival functions for patients with tumours exhibiting a well defined border with prominent inflammatory reaction, including perivascular cuffs and no desmoplasia (baseline characteristics), and patients in whom corresponding unfavourable characteristics are operating in concert. Standardised to moderately differentiated Dukes' class B rectal cancers. Proportion surviving five years indicated.

$516(68 \%)$ for the other tumours $(p<0.001)$. The proportion of tumours with a poorly defined margin and the prevalence of perivascular "cuffs" were similar in signet ring-cell carcinomas and other tumours.

Sex and tumour site were not associated with any of the tumour border characteristics except that perivascular cuffs were found in 180 of $256(70 \%)$ of the tumours in women compared with 165 of $271(61 \%)$ of those in men $(p<0.05)$.

A prominent inflammatory infiltrate, many eosinophils, abscess formation, and lack of desmoplasia were significantly more common in tumours with well defined borders than in those with poorly defined borders (table 3). Perivascular lymphocytic cuffs were not related to the growth pattern. Such cuffs, however, were found in 144 of $181(80 \%)$ of the tumours with prominent inflammatory reaction at the tumour border, compared with 201 of $346(58 \%)$ of those with inconspicuous inflammatory reaction $(\mathrm{p}<0.001)$.

The $\kappa$ indexes of reproducibility of the evaluation of the tumour border characteristics were in the range 0.73 to 0.86 (with $95 \%$ confidence intervals ranging from 0.63 to 0.94 ), except for the evaluation of eosinophilic infiltrates, for which $\kappa$ was 0.39 (with the $95 \%$ confidence interval ranging from 0.03 to 0.75 ).

Although several of the tumour border characteristics were correlated with clinicopathological stage (table 1) and in some ways were inter-related (table 3), 
the results presented in table 4 show that a poorly defined tumour border, desmoplastic reaction, lack of a conspicuous inflammatory infiltrate and lack of perivascular lymphocytic "cuffs" each independently implied an increase in risk of death by a factor of about 1.5 compared with the corresponding baseline characteristics. Clinicopathological stage, though, had the strongest influence on prognosis.

The variables of sex, age, amount of mucin content in the adenocarcinomas, eosinophilia of the inflammatory infiltrate, and abscess formation had no significant independent influence on the survival.

The overall five year survival (Kaplan-Meier estimate) in the series was $53.7 \%$ (with the $95 \%$ confidence interval ranging from $49 \cdot 1$ to $58 \cdot 3 \%$ ). Fig 3 illustrates the influence on the estimated survival function of the tumour border characteristics studied in this series.

\section{Discussion}

This study shows that invasiveness and other histological variables which may have prognostic importance in colorectal cancer are often associated with each other, as well as with clinicopathological stage. The complexity of these associations requires multivariate analyses to be carried out to determine whether the variables may have an independent influence on prognosis and to evaluate their importance. Cox's proportional hazards regression analysis has corroborated the data obtained in recent, large multivariate analyses of rectal cancer ${ }^{40}$ in which an irregular growth pattern at the tumour border and a scanty lymphocytic infiltration were independently associated with a poor prognosis.

Despite numerous studies that have characterised the cellular composition of the inflammatory infiltrates surrounding colorectal cancers, the biological role of the individual cell types remains unclear. ${ }^{3922-24}$ Jass suggested that the lymphocytic infiltration in colorectal cancer reflected a conservation of the normal interactive traffic between epithelium and mucosa-associated lymphoid tissue, and signalled a low grade growth. ${ }^{10}$

Pihl et al regarded perivascular lymphocytic cuffs as a beneficial immunomorphological feature, ${ }^{7}$ although there are no direct observations to indicate that the lymphocytes of the cuffs are actively defensive. Our study suggests that such cuffs have an independent beneficial influence on the prognosis, but our findings do not explain the mechanisms of this effect. It is tempting to hypothesise that leucocytes and macrophages attracted by chemotaxis (from infection and tumour necrosis) might benefit the host resistance through non-immunological attack on tumour cells. In this study, however, we were unable to find any prognostic importance for abscess formation.

Eosinophilic infiltrates in carcinomas of the colon have been reported to be associated with an improved prognosis. ${ }^{25}$ We were unable to find any independent prognostic influence of eosinophilic infiltrates. The reproducibility of this part of the histological evaluation, however, was poor.

Tumour desmoplasia is a common feature in several malignant human tumours - breast, bowel, and prostate cancer. Jass could not find any prognostic influence for tumour fibrosis in rectal cancer. ${ }^{10}$ By contrast, the results of our study suggest that tumour desmoplasia is an independent prognostic variable which may increase the risk of death by a factor of about 1.5 compared with tumours with little or no fibrosis.

Martin et al reported a beneficial effect of fibroblastic reaction in colonic cancer in rats and suggested that fibrous encapsulation could have a role in the mechanism of tumour regression. ${ }^{14}$ Others have argued that such an encapsulation might benefit the tumour by reducing access by host immune cells. ${ }^{12}$ Our results favour the latter view.

Jass and Morson have recently proposed a system of prognostic categorisation for colorectal cancer which takes heed of the clinicopathological stage, as well as the character of the invasive margin, and the presence or absence of a conspicuous peritumoural lymphocytic infiltrate. ${ }^{26} \mathrm{We}$ suggest that the degree of peritumoural fibrosis (desmoplasia) and the presence or absence of perivascular lymphocytic cuffs give additional information about prognosis in colorectal cancer.

We thank the staff at the Cancer Registry of Norway, Oslo for providing survival data, Mrs Mette Heim for technical assistance, and Mrs Sigrum $\varphi$ rnsj $\phi$ for typing the manuscript.

This study was financially supported by grants from Kreftfondet ved Regionsykehuset i Trondheim.

\section{References}

1 Grinnell RS. The grading and prognosis of carcinoma of the colon and rectum. Ann Surg 1939;109:500-33.

2 Spratt JS, Spjut HJ. Prevalence and prognosis of individual clinical and pathologic variables associated with colorectal carcinoma. Cancer 1967;20:1976-85.

3 Thynne GS, Weiland LH, Moertel CG, Silvers A. Correlation of histopathologic characteristics of primary tumour and uninvolved regional lymph nodes in Dukes' class $C$ colonic carcinoma with prognosis. Mayo Clin Proc 1980;55:243-5.

4 Jass JR, Atkin WS, Cuzick J, et al. The grading of rectal cancer: historical perspectives and a multivariate analysis of 447 cases. Histopathology 1986;10:437-59.

5 Underwood JCE. Lymphoreticular infiltration in human tumours: prognostic and biological implications: a review. $\mathrm{Br} J$ Cancer 1974;30:538-48. 
6 Murray D, Hreno A, Dutton J, Hampson LG. Prognosis in colon cancer. A pathologic reassessment. Archives of Surgery 1975;110:908-13.

7 Pihl E, Malahy MA, Khankhanian N, Hersh EM, Mavligit GM. Immunomorphological features of prognostic significance in Dukes' class B colorectal carcinoma. Cancer Res 1977;37: 4145-9.

8 Zamcheck N, Doos WG, Prudente R, Lurie BB, Gottlieb LS. Prognostic factors in colon carcinoma. Correlation of serum carcinoembryonic antigen level and tumor histopathology. Hum Pathol 1975;6:31-45.

9 Svennevig JL, Lunde OC, Holter J, Bjфrgsvik D. Lymphoid infiltration and prognosis in colorectal carcinoma. Br J Cancer 1984;49:375-7.

10 Jass JR. Lymphocytic infiltration and survival in rectal cancer. $J$ Clin Pathol 1986;39:585-9.

11 Bjerkeset T, Morild I, M $\phi$ rk S, S $\phi$ reide O. Tumor characteristics in colorectal cancer and their relationship to treatment and prognosis. Dis Colon Rectum 1987;30:934-8.

12 Liotta LA, Rao CN, Barsky SH. Tumor invasion and the extracellular matrix. Lab Invest 1983;49:636-49.

13 Dvorak HF. Tumours: wounds that do not heal. Similarities between tumour stroma generation and wound healing. $N$ Engl J Med 1986;315:1650-8.

14 Martin MS, Caignard A, Hammann A, Pelletier H, Martin F. An immunohistological study of cells infiltrating progressive and regressive tumors induced by the two variant subpopulations of a rat colon cancer cell line. Int J Cancer 1987;40:87-93.

15 Halvorsen TB, Seim E. Degree of differentiation in colorectal adenocarcinomas: a multivariate analysis of the influence on survival. J Clin Pathol 1988;41:532-7.

16 Halvorsen TB, Seim E. Influence of mucinous components on survival in colorectal adenocarcinomas: a multivariate analysis. J Clin Pathol 1988;41:1068-72.

17 Halvorsen TB, Seim E. Tumour site: a prognostic factor in colorectal cancer? A multivariate analysis. Scand J Gastroenterol 1987;22:124-8.

18 Dukes CE. The classification of cancer of the rectum. J Pathol Bacteriol 1932;35:323-32.

19 Cox DR. Regression models and life-tables. $J$ R Statist Soc (B) 1972;34:187-220.

20 Dixon WJ. BMDP statistical software. Berkeley, California: University of California Press, 1983.

21 Cohen J. A coefficient of agreement for nominal scales. Educational and Psychological Measurement 1960;26:37-46.

22 Vose BM, Gallagher P, Moore M, Schofield PF. Specific and nonspecific lymphocyte cytotoxicity in colon carcinoma. $\mathrm{Br} J$ Cancer 1981;44:846-55.

23 Csiba A, Whitwell HL, Moore M. Distribution of histocompatibility and leucocyte differentiation antigens in normal human colon and in benign and malignant colonic neoplasms. Br J Cancer 1984;50:699-709.

24 Koch B, Giedl J, Hermanek P, Kalden JR. The analysis of mononuclear cell infiltrations in colorectal adenocarcinoma. $J$ Cancer Res Clin Oncol 1985;109:142-51.

25 Pretlow TP, Keith EF, Cryar AK, et al. Eosinophilic infiltration of human colonic carcinomas as prognostic indicator. Cancer Res 1983;43:2997-3000.

26 Jass JR, Morson BC. Reporting colorectal cancer. J Clin Pathol 1987;40:1016-23.

Requests for reprints to: Dr Tore B Halvorsen, Department of Pathology, Trondheim Regional and University Hospital, N-7006 Trondheim, Norway. 